\title{
Analisis Kebijakan Pemerintah Daerah Dalam Penanganan Covid-19: Perspektif Hukum Administrasi
}

\author{
Ardika Nurfurqon
}

Fakultas Politik Pemerintahan, IPDN, ardhikanur@gmail.com

\begin{abstract}
This study aims to find out the Analysis of Regional Government Policy in Handling Covid-19 perspectives of Administrative Law. With qualitative research approaches using normative legal research. Both the central and regional governments reduce the spread of Covid-19 with some handling, especially in the perspective of administrative law. In this case, an analysis of West Bandung Regency is needed in the handling of Covid-19. This gives an understanding that the regional government in making policy needs to synchronize with the central government, especially in analyzing a policy in Based on administrative law perspective.
\end{abstract}

Keywords: Policy Analysis; Covid-19; Administrative Law.

\begin{abstract}
Abstrak
Penelitian ini bertujuan untuk menggetahui Analisis Kebijakan Pemerintahan Daerah dalam Penanganan Covid-19 perspektih Hukum Administrasi. Dengan penelitian kualitatif dengan pendekatan menggunakan penelitian hukum normatif. Pemerintah baik pusat maupun daerah menekan angka penyebaran Covid-19 dengan beberapa penanganan terutama dalam perpektif hukum administrasi. Dalam hal ini dibutuhkan analisis kebijakan daerah Kabupaten Bandung Barat dalam penanganan Covid-19. Hal ini memberi pengertian bahwa pemerintah daerah dalam membuat kebijkan perlu adanya sinkronisasi dengan pemerintah pusat terutama dalam menganalisis suatu kebijakan sesuai dengan hukum administrasi negara.
\end{abstract}

Kata Kunci: Analisis Kebijakan; Covid-19; Hukum Administrasi.

\section{Pendahuluan}

SARS-CoV-2 atau yang lebih dikenal dengan istilah Virus Corona merupakan virus yang menyebabkan pandemi Covid-19. Virus ini diketahui pertama kali penyebarannnya di kota Wuhan, China akhir Desember 2019. Pandemi tersebut menyebar dan menjadi pembahasan dalam berbagai media seluruh dunia. Seluruh pemerintah di setiap negara berupaya meminimalisir angka penyebaran termasuk Organisasi Kesehatan Dunia (WHO) yang telah memberikan peringatan tentang bahaya pandemi Covid-19.

Indonesia termasuk negara yang berupaya meminimalisir pencegahan penyebaran Covid19. Kasus pertama kali terjadi penyebaran virus corona di Indonesia yaitu 2 (dua) warga Kota Depok, Jawa Barat yang diumumkan oleh Presiden Joko Widodo pada hari Senin, 2 Maret 2020. Sejak saat itu, pandemi ini menyebar dengan cepat hingga ke berbagai wilayah. Dilansir

\section{Jurnal}

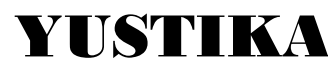

Media Hubum dan Keadilan Fakultas Hukum Universitas Surabayo ol. 23 No. 01, Juli 2020 E-ISSN: 2655-7479 kompas.com pada 07 April 2020 di Indonesia sudah terjadi sebanyak 2738 Kasus, dimana 2313 dirawat, 221 meninggal dunia dan 204 sembuh. Ini hampir $10 \%$ meninggal dunia dari jumlah kasus. (Kompas, 2020)

Selain itu pandemi corona ini banyak menimbulkan efek negatif diantaranya dalam bidang pendidikan, perdagangan, industri, pariwisata, ekonomi dan lainnya. Contohnya saja dalam bidang ekonomi, karena banyaknya kegiatan yang lumpuh maka berimbas pada perekonomian 
bahkan nilai tukar rupiah merosot hingga tembus diatas 16.000 rupiah /Dollar U.S.A. Dari banyaknya korban jiwa serta besarnya efek dari pandemi corona, bukan berarti pemerintah tidak melakukan apapun. Beberapa strategi dan kebijakan yang dibuat dalam pencegahan penyebaran serta penularan yang mengakibatkan kematian dari penyakit ini. Tetapi banyak kebijakan tersebut yang dirasakan tidak sesuai dan tidak tepat, sehingga kebijakan tersebut tidak luput dari kritikan mulai dari politisi, praktisi, akademisi hingga masyarakat umumnya.

Terlepas dari kebijakan-kebijakan tersebut, salah satu hal penting ialah sinergitas antara pemerintah pusat yang memegang peran penting dalam pengambilan kebijakan dengan pemerintah daerah serta antisipasi cepat yang dilakukan pemerintah daerah dalam penanggulangan serta pencegahan virus corona ini. Karena pemerintah daerah dirasa lebih dekat dengan masyarakat oleh karenanya berbagai kebijakan akan dirasa lebih efektif, sebagai mana dikatakan oleh (O'Toole,1986) bahwa kinerja kebijakan dapat dipengaruhi oleh kondisi diantaranya lingkungan politik, sosial, dan ekonomi yang dapat mempengaruhi kebijakan, sehingga kebijakan tersebut diimplementasikan (Agus Purwanto, 2012). Oleh karena itu tepatlah ketika Pemerintah Pusat benar-benar menggandeng Pemerintah Daerah sebagai partner dalam menyelsaikan problem ini, dimana Pemerintah Daerah lebih tahu akan karakteristik masyarakat serta wilayahnya sendiri. Namun bukan berarti juga Pemerintah Daerah bisa berbuat semaunya sendiri, tetap harus berdasar pada landasan hukum yang jelas dan mengikuti langkah-langkah administratif yang benar. Untuk mengetahui hal itu maka ditulislah makalah ini serta mengambil studi kasus disalah satu kabupaten yaitu Kabupaten Bandung Barat. Sehingga penulis memberikan rumusan permasalahan tentang apa yang dimaksud kebijakan dalam perspektif Hukum Administrasi dan analisis kebijakan Pemerintah Daerah dalam melaksanakan karantina wilayah untuk penanganan Covid-19?

\section{Metode Penelitian}

Metodologi ini menggunakan metode kualitatif dengan berfokus pada pemahaman terhadap fenomena sosial di masyarakat (Sugiyono, 2008). Adapun teknik atau pendekatan yang dilakukan ialah dengan cara Teknik Pengumpulan Data dengan Dokumen, dimana disini penulis mengumpulkan Undang-undang, Buku Literasi dan Jurnal Ilmiah sebagai bahan data untuk memudhkan penulis dalam melakukan analisis.

Penelitian ini diterapkan dengan menggunakan penelitian hukum normatif. Atau disebut juga dengan istilah penelitian studi pustaka yang memakai sebagai mahan penelitiannya. Adapun dokumen-dokumen tersebut seperti peraturan atau perundang-undangan, buku, jurnal ilmiah dan berita dari media yang kredibel dan dapat dipertanggungjawabkan.

\section{Hasil Penelitian dan Pembahasan}

\subsection{Kebijakan Publik Perspektif Hukum Administrasi}

\subsubsection{Kebijakan}

(Abdul Wahab, 2012) mengatakan bahwa "kebijakan adalah apapun cakupanya, sesungguhnya merupakan tindakan-tindakan terpola, yang menngarah pada tujuan tertentu yang disepakati dan bukan sekedar keputusan acak untuk melakukan sesuatu." Sementara (Ismail Nawawi, 2009) menyatakan "Kebijakan adalah prinsip atau cara bertindak yang dipilih untuk mengarahkan pengambilan keputusan". Disisi lain Easton menyebutkan kebijakan pemerintah sebagai "kekuasaan pengalokasian nilai-nilai untuk masyarakat secara keseluruhan". 
Jurnal Yustika

Vol. 23 No. 01, Jul 2020

Halaman | 15

Analisis Kebijakan

Pemerintah Daerah dalam Penanganan Covid-19:

Perspektif Hukum

Administrasi

Ardika Nurfurqon

\subsubsection{Kebijakan Publik}

Pengertian Kebijakan menurut Anderson dalam (Winarno, 2012) menjelaskan sebagai berikut: "kebijakan adalah arah tindakan yang mempunyai maksud yang ditetapkan oleh seorang actor atau sejumlah actor dalam mengatasi suatu masalah atau suatu persoalan".Sedangkan Publik Menurut Sinambela publik yang berasal dari Bahasa Inggris yaitu public yang artinya umum, masyarakat, atau negara.

Dalam konsep kebijakan publik, banyak pendapat yang memberikan makna berbeda-beda, tetapi konsep tersebut memberikan makna tentang kebijkan publik. Konsep tersebut justru memberikan penjelasan tentang kedalaman analisis guna merumuskan terkait batasan-batasan kosep kebijkan publik. Penulis menjelaskan pendapat-pendapat para ahli tentang definisi kebijkan publik guna keperluan anlisis dalam penulisan ini diantaranya adalah Robert Eyestone (dalam Winarno, 2012:17) yang berpendapat bahwa secara luas kebijakan publik (public policy) itu dapat didefinisikan sebagai hubungan suatu unit pemerintah dengan lingkungannya.

Selanjutnya Harold D. Lasswel dan Abraham Kaplan dalam (Islamy, 2009:15-16) memberikan arti kebijaksanaan sebagai "a projected program of goals, values and practices" (suatu program pencapaian tujuan, nilai-nilai dan praktek-praktek yang terarah).

Pendapat di atas lebih menekankan bahwa kebijaksanaan itu adalah program yang mempunyai tujuan untuk dicapai. Kemudian (Nugroho, 2012) mengatakan bahwa kebijakan publik (public policy) adalah :

“jalan mencapai tujuan bersama yang dicita-citakan. Jika cita-cita bangsa Indonesia adalah mencapai masayarakat yang adil dan makmur berdasarkan Pancasila (Ketuhanan, Kemanusiaan, Persatuan, Demokrasi, dan Keadilan) dan UUD 1945

(Negara Kesatuan Republik Indonesia yang berdasrkan hukum dan tidak sematamata kekuasaan), maka kebijakan publik adalah seluruh prasarana dan sarana untuk mencapai "tempat tujuan" tersebut."

Berdasarkan definisi konsep kebijakan publik di atas, maka didalam kebijakan publik haruslah mempunyai atau mengandung tujuan atau sasaran yang ingin atau akan dicapai. Makna kebijakan publik seringkali dikaitkan atau diberikan makna sebagai tindakan politik, makna kebijakan publik tersebut senada dengan pendapat W.I. Jenkins dalam (Abdul Wahab, 2012) yang mengatakan kebijakan publik (public policy) merupakan :

"a set of interrelated decisions taken bay a political actor or group of achieving them within a specified situation where these decisions should, in principle, be within the power of these actors to achieve"

(Serangkaian keputusan yang saling berkaitan yang diambil oleh seorang aktor politik atau kelompok aktor politik berkenaan dengan tujuan yang telah dipilih beserta cara-cara untuk mencapainya dalam suatu situasi dimana keputusankeputusan itu pada prinsipnya masih berada dalam batas-batas kewenangan kekuasaan dari para aktor tersebut).

Chief J.O. Udoji mempunyai pandangan sedikit berbeda dengan pendapat W.I. Jenkins di atas, Chief J.O. Udoji lebih menekankan kebijakan publik (public policy) itu pada tujuan tertentu dan dapat mempengaruhi masyarakat. Adapun definisi kebijakan publik (public policy) menurut Chief J.O. Udoji (dalam Wahab, 2012:5) yaitu sebagai 
berikut " a sanctioned course of action addressed to a particular problem or group of related problems that affect society at large" (suatu tindakan bersanksi yang mengarah pada suatu tujuan tertentu yang saling berkaitan yang mempengaruhi sebagian besar warga masayarakat).

Berdasarkan pengertian-pengertian di atas tentang kebijkan publik yang dikemukakan para ilmuan, maka dapat dijelaskan tentang bagaimana kebijakan publik mempunyai pengertian dimensi yang luas dan sangat dinamis, sehingga dapat menjadi pengembangan ilmu yang lebih lanjut dan kebijaksaaan publik juga dapat diartikan sebagai rangkaian keputusan atau tindakan yang ditetapkan oleh pemerintah yang didalamnya terdapat tahapan-tahapan yang saling berkaitan serta mempunyai tujuan yang akan dicapai.

Dalam penelitian ini penulis juga mengutif padangan anderson dalam (Islamy, 2009:17) yang mengatakan kebijakan publik (public policy) merupakan rangkaian tindakan yang mempunyai tujuan tertentu yang diikuti dan dilaksanakan oleh seorang pelaku atau sekelompok pelaku guna memecahkan suatu masalah tertentu. Dari pandangan anderson ini maka dapat disimpulkan bahwa setiap kebijaksanaan itu pastilah mempunyai tujuan tertentu untuk memecahkan suatu masalah tertentu, dan tujuan tersebut dapat dicapai apabila kebijaksanaan tersebut dapat dijalankan dengan baik.

\subsection{Analisis Kebijakan publik}

Carl W. Patton dan David S. Savicky dalam (Dwijowijoto, 2004: 84) menjelaskan bahwa analisis kebijaksanaan (policy analysis) adalah tindakan yang diperlukan untuk dibuatnya sebuah kebijaksanaan, baik kebijaksanaan yang baru sama sekali, atau kebijaksanaan yang baru sebagai konsekuensi dari kebijaksanaan yang ada.Analisis kebijakan mempunyai lima prosedur, adapun ke lima prosedur tersebut dapat digambarkan sebagai berikut :

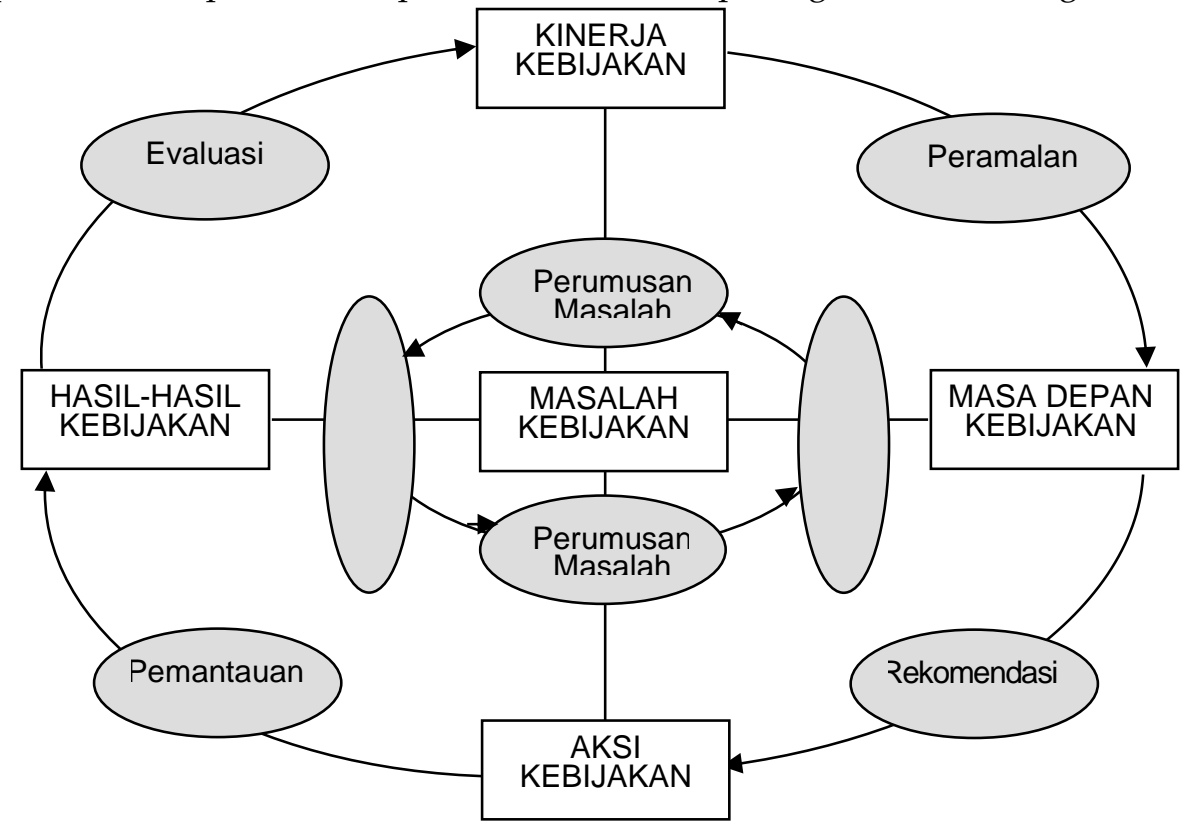

Gambar 1.1. Analisis Kebijakan yang Berorientasi pada Masalah

Sumber, Dunn (2000:21) 
Jurnal Yustika

Vol. 23 No. 01, Jul 2020

Halaman | 17 Analisis Kebijakan Pemerintah Daerah dalam Penanganan Covid-19: Perspektif Hukum Administrasi

Ardika Nurfurqon
Dari gambar 1.1. di atas maka diketahui bahwa dalam penggunaan dalam prosedur analisis kebijakan (seperti perumusan masalah, peramalan, pemantauan, evaluasi, rekomendasi) kemungkinan dapat memberikan tentang analisis mentransformasikan dari satu informasi informasi yang lainnya.

Ada tiga bentuk utama analisis kebijakan (policy analysis) menurut (Dunn 2000), yaitu analisis prospektif, retrospektif dan terintegrasi. Analisis prospektif merupakan analisis yang berupa produksi dan transformasi informasi sebelum aksi kebijakan dimulai dan diimplementasikan, analisis retrospektif berupa produksi dan transformasi informasi sesudah aksi kebijakan dimulai dan diimplementasikan sedangkan analisis terintegrasi adalah bentuk analisis yang mengkombinasikan gaya operasi para praktisi yang menaruh perhatian pada penciptaan dan transformasi informasi sebelum dan sesudah tindakan kebijakan diambil sehingga dapat dikatakan bahwa analisis kebijakan terintegrasi merupakan gabungan dari kedua bentuk analisis tersebut.

\subsubsection{Hukum Administrasi}

Sebagaimana dijelaskan dalam buku Hukum Administrasi Nagara (Prajudi Atmosudirjdjo 1983) tentang pengertian Hukum Administrasi dalam arti luas yang terdiri dalam lima unsur, yaitu:

1. Hukum Administrasi sebagai unsur Hukum Tata Pemerintahan Dalam bukunya dijelaskan bahwa Hukum Tata Pemerintahan adalah hukum Eksekutif atau yang disebut hukum tata pelaksanaan Undang-Undang, atau mengenai control dalam penggunaan kekuasaan publik (dimana kekuasaan berada pada Kedaulatan Negara);

2. Hukum Administrasi sebagai unsur Hukum Tata Usaha Negara Hukum Tata Usaha Negara adalah hukum mengenai surat-menyurat, rahasia jabatan dan dinas, kearsipan, registrasi dan dokumentasi, pelaporan, legalisasi dan statistic, tatacara penyimpanan dan penyusunan berita acara, publikasi, pencatatan sipil, pencatatan NTR, penerangan dan penerbitanpenerbitan negara. Istilah lain Hukum Tata Usaha Negara yaitu Hukum Birokrasi

3. Hukum Administrasi sebagai unsur hukum administrasi dalam arti sempit yang merupakan Hukum Pengurusan Rumah Tangga Negara, intern dan ekstern;

Rumah Tangga Intern adalah yang berkaitan dengan urusan intern instansiintansi Administrasi seperti: urusan kesejahtaraan dan personil pegawai neger, urusan materil, urusan keuangan operasional, alat kelengkapan, dan gedung serta perumahan, urusan transportasi, urusan komunikasi dan sebagainya

Rumah tangga ekstern ialah urusan-urusan yang sebelumnya diselenggarakan oleh masyarakat, tetapi dengan adanya berbagai sebab sehingga menjasi urusan Negara melalui dinas-dinas, lembaga, dan badan;

4. Sebagai unsur Hukum Administrasi Pembangunan yaitu yang mengatur penyelenggaraan pembangunan;

5. Hukum Administrasi sebagai unsur Hukum Administrasi Lingkungan.

\subsubsection{Hukum Administrasi Daerah}


Dalam (Prajudi Atmosudirjdjo, 1983) pengertian Hukum Administrasi Daerah adalah: 1) hukum yang mengatur seluk-beluk daripada pemerintahan dan administrasi daerah (Hukum Administrasi Daerah heteronom) dan 2) hukum yang dicipta oleh pemerintahan/administrasi daerah sendiri (Hukum Administrasi daerah otonom).

Sumber-sumber hukum daripada Hukum Administrasi heteronom daerah ialah: 1) UUD 1945 (pasal 18), 2) Ketetapan-ketetapan MPR, 3) UU, khususnya UU Nomor 9 Tahun 2015, 4) Peraturan Pemerintah, 5) Keputusan Presiden, dan 6) Peraturan Menteri khususnya Menteri Dalam Negeri.

Hukum Administrasi Daerah heteronom tersebut mengatur status daripada Daerah Otonom, mengatur tugas fungsi dan kewajiban daripada organ-organ daerah dan mengatur struktur organisasi daerah.

Sumber hukum pada Hukum Administrasi Daerah terdiri dari: 1) Peraturan Daerah 2) Peraturan Kepala Daerah yang bersangkutan dan 3) Peraturan dan Keputusan Kepala daerah. Sehingga Hukum Administrasi Daerah otonom menjadi bersifat interpretasi, penjabaran dan operasional-prosedural. (Prajudi Atmosudirdjo, 1994)

\subsection{Studi Kasus Kebijakan Pemerintah Daerah Kabupaten Bandung Barat Melaksanakan Karantina Wilayah Untuk Penanganan Covid-19}

Disini penulis mengambil Kabupaten Bandung Barat sebagai wilayah yang akan dianalisis kebijakan pemerintah daerahanya mengenai kebijakan Pemerintah Daerah dalam melaksanakan karantina wilayah untuk penanganan Covid-19 berdasarkan dalam perspektif Hukum Administrasi. Sebelum dilanjut ke analisis baiknya kita mengenal sedikit wilayah dari Kabupaten Bandung Barat sendiri.

Gambaran umum Kabupaten Bandung Barat yang merupakan salah satu wilayah kabupaten hasil pemekaran dari Kabupaen Bandung yang berada Provinsi Jawa Barat, oleh karena itu Kabupaten Bandung Barat menjadi Kabupaten secara definitif berdasarkan Undang-Undang Nomor 12 Tahun 2007 tentang Pembentukan Kabupaten Bandung Barat di Provinsi Jawa Barat (Lembaran Negara Republik Indonesia Tahun 2007 Nomor 12, Tambahan Lembaran Negara republik Indonesia Nomor 4688).

Secara geografis Kabupaten Bandung Barat terletak pada $107^{\circ} 22^{\prime}-108^{\circ} 05^{\prime}$ Bujur Timur dan $06^{\circ} 41^{\prime}-07^{\circ} 19^{\prime}$ Lintang Selatan. Wilayah Kabupaten Bandung Barat memiliki luas wilayah 130.577,40 Ha atau 1.305,77 Km2 sehingga terbagi menjadi 16 wilayah administrasi kecamatan, yaitu Lembang, Cisarua, Parongpong, Cikalongwetan, Ngamprah, Cipeundeuy, Padalarang, Cipatat, Batujajar, Cililin, Cihampelas, Rongga, Cipongkor, Sindangkerta, Saguling dan Gununghalu. Kabupaten Bandung Barat mempunyai 165 desa, dengan batas wilayah administrasi meliputi: a. Sebelah Utara : berbatasan dengan Kecamatan Cikalong Kulon Kabupaten Purwakarta; Kecamatan (Jalan Cagak, Sagalaherang dan Cisalak) Kabupaten Cianjur; Kecamatan (Bojong, Maniis, Wanayasa, dan Darangdan) Kabupaten Subang. b. Sebelah Timur : berbatasan dengan Kecamatan (Cimenyan, Cilengkrang, Margaasih dan Soreang) Kabupaten Bandung, Kecamatan (Sukasari dan Cidadap ) Kota Bandung dan Kecamatan (Cimahi Tengah, Cimahi Selatan dan Cimahi Utara) Kota Cimahi. c. Sebelah Barat : berbatasan dengan Kecamatan (Mande, Campaka, dan Ciranjang) Kabupaten Cianjur. d. Sebelah Selatan : Berbatasan Kabupaten Cianjur dan Kabupaten Bandung. 
Jurnal Yustika

Vol. 23 No. 01, Jul 2020

Halaman I 19 Analisis Kebijakan Pemerintah Daerah dalam Penanganan Covid-19: Perspektif Hukum Administrasi

Ardika Nurfurqon
Kabupaten Bandung Barat merupakan daerah yang memiliki pemandangan yang indar serta daerah yang subur dengan kondisi geografis yang potensial (berbukitbukit dengan ketinggian dan kemiringan yang variatif) dengan dataran terendah pada ketinggian $125 \mathrm{~m}$ dpl dan dataran tertinggi pada ketinggian $2.150 \mathrm{~m}$ dpl. Kawasan perkotaan Bandung Barat berkembang di kawasan tengah atau di kawasan yang relatif datar di sekitar wilayah Kota Padalarang. (RPJM Pemda Kabupaten Bandung Barat, 2010)

Disini penulis akan menganalisis beberapa kebijakan Pemerintah Daerah mengenai penanganan kasus khususnya karantina wilayah untuk pencegahan Covid-19. Sudah disebutkan diatas bahwa Covid-19 ini telah masuk ke Indonesia tertanggal 02 Maret 2020, Presiden Ir. Joko Widodo mengumumkan kasus Covid-19 tersebut secara langsung di Istana Negara. Sejak kasus pertama tersebut korban mulai berjatuhan hingga ratusan jiwa meninggal dunia. Tercatat di Kabupaten Bandung Barat sendiri terdapat 101 Kasus dimana 2 diantarnya positif, 3 Pasien Dalam Perawatan dan 96 Orang Dalam Pemantauan. (Dinas Kesehatan Kabupaten Bandung Barat, 2020) Pemerintah Pusat disini tentu mengeluarkan kebijakan-kebijakan guna mengatasi tersebut. Bukan hanya kebijakan mengenai pencegahan Covid-19 tetapi juga dengan kebijakan-kebijakan untuk memenuhi kebutuhan masyarakat selama pandemi ini.

Pemerintah Daerah Kabupaten Bandung Barat yang merupakan sebagai salah satu daerah otonom di Indonesia tentu harus mengikuti berbagai kebijakan yang dikeluarkan pemerintah pusat. Selain itu Pemerintah Daerah Kabupaten Bandung Barat sendiri berhak mengelurkan kebijakan sendiri untuk menanggulangi pandemi Covid-19 ini untuk di daerahnya yang tentunya harus adanya keselarasan dengan pemerintah pusat atau tidak keluar jalur dari batasan-batasan atau aturan yang dikeluarkan oleh Pemerintah Pusat.

Berikut adalah aturan dan edaran yang dikeluarkan oleh Pemerintah Kabupaten Bandung Barat selama karantina wilayah dalam rangka pencegahan Covid-19:

1) Peraturan Bupati Bandung Barat Nomor 20 Tahun 2020 tentang Pelaksanaan Pembatasan Sosial Berskala Besar Dalam Penanganan Corona Virus Diesiase 2019 di Wilayah Kabupaten Bandung Barat

2) Surat Edaran Bupati Nomor 556/625 Disparbud Tentang Upaya Preventif Pencegahan Virus Corona di Sektor Pariwisata dan ekonomi Kreatif di Kabupaten Bandung Barat

3) Surat Edaran Bupati Nomor 420/664 Dinkes Tentang Peningkatan Kewaspadaan Menghadapi Covid-19 di Kabupaten Bandung Barat

4) Surat Edaran Nomor 440/665 Disdik Tentang Antisipasi Penyebaran Covid-19 pada Satuan Pendidikan di Kabupaten Bandung Barat

5) Himbauan Bupati Terkait Covid-19

6) Surat Edaran Bupati Nomor 440/600 Dinkes Tentang Peningkatan Kewaspadaan dan Kesiagapan Menghadapi Infeksi Virus Corona (Covid-19) di Kabupaten Bandung Barat

7) Surat Edaran Bupati Nomor 440/846 Disperindag Tentang Pembatasan waktu Operasional Pelaku Usaha Toko Modern, Pasar Modern, Grosir, Pasar Tradisional/Rakyat dan Pasar Desa Dalam Upaya Percepatan Penanganan Covid19 di Kabupaten Bandung Barat 
8) Surat Edaran Dinas Pendidikan Kabupaten Bandung Barat Nomor 420/898 Tentang Perpanjangan Masa Belajar Di Rumah Bagi Peserta Didik TK, PAUD, SD, SMP, SKB, LKP, LPK, dan PKBM di Kabupaten Bandung Barat

Melihat aturan-aturan diatas memperlihatkan bahwa Pemerintah Daerah Kabupaten Bandung Barat mengikuti alur dari apa yang dikeluarkan oleh kebijakan pusat dalam melakukan pencegahan dan penanganan Covid-19. Paraturan Bupati dan Surat-surat Edaran yang dikeluarkan tentu berdasarkan aturan-aturan pusat. Sebagai contoh Peraturan Bupati Bandung Barat Nomor 20 Tahun 2020 tentang Pelaksanaan Pembatasan Sosial Berskala Besar Dalam Penanganan Corona Virus Diesiase 2019 di Wilayah Kabupaten Bandung Barat yang dikeluarkan pada 20 April 2020 yang merupakan tindaklanjut Peraturan Pemerintah (PP) No. 21/2020 tentang Pembatasan Sosial Berskala Besar (PSBB) Dalam Rangka Percepatan Penanganan Covid-19 serta Surat Edaran Nomor 440/665 Disdik Tentang Antisipasi Penyebaran Covid-19 pada Satuan Pendidikan di Kabupaten Bandung Barat, Surat Edaran yang dikeluarkan pada tanggal 13 Maret 2020 ini dikeluarkan atas dasar menindaklanjuti Surat Edaran Menteri Pendidikan dan Kebudayaan Nomor 3 Tahun 2020 tertanggal 9 Maret 2020 tentang Pencegahan Covid-19 pada Satuan Pendidikandan Surat Edaran Gubernur Jawa Barat Nomor 400/27/HUKHAM, tanggal 13 Maret Tahun 2020 tentang Peningkatan Kewaspadaan terhadap Resiko Penularan Covid-19. Sama halnya dengan Surat Edaran Nomor 420/898 Disdik Tentang Perpanjangan Masa Belajar Di Rumah Bagi Peserta Didik TK, PAUD, SD, SMP, SKB, LKP, LPK, dan PKBM di Kabupaten Bandung Barat. Surat Edaran ini dikeluarkan tertanggal 9 April 2020 berdasarkan atas Surat Edaran Kemenpan RB Nomor 34 Tahun 2020 tentang Perubahan Atas Surat Edaran Menteri PAN RB Nomor 19 Tahun 2020 tentang Penyesuaian Sistem Kerja ASN dan Upaya Pencegahan Covid-19 di Lingkungan Instansi Pemerintahan.

Melihat kedua contoh diatas bahwa Surat Edaran Bupati Bandung Barat dikeluarkan tidak semata-mata karena keinginan dan kebutuhan Pemerintah Daerah sendiri melainkan atas dasar aturan yang berada diatasnya, begitupun dengan surat edaran ataupun kebijakan lainnya yang dikeluarkan oleh Pemerintah Daerah. Hal ini sesuai dengan apa yang dikemukakan oleh Prof. Pradjudi Atmosudirjo bahwa sumber-sumber Hukum Administrasi Daerah ialah Peraturan-peraturan yang berada diatasnya yang berkaitan dengan pemerintah daerah.

Selain itu Pemerintah Daerah Kabupaten Bandung Barat melakukan Kebijakankebijakan lain seperti gelontoran dana sebesar 18 Miliyar untuk pencegahan dan penanggulangan Covid-19 di Bandung Barat, Mengakomori beberapa pasar tradisional untuk melayani pembeli secara online yang sudah dilakukan di 9 Pasar Tradisional, Penyemprotan Disinfektan di Tempat-tempat Umum, Penyediaan Paket Beras dan Sayuran yang dikoordinir oleh Dinas Pertanian dan Ketahanan Pangan Kabupaten Bandung Barat dan beberapa kebijakan lainnya (Dinas kesehatan KBB, 2020). Hal-hal tersebut dilakukan sebagai upaya karantina wilayah di Kabupaten Bandung Barat guna pencegahan Covid-19. Tentunya berbagai hal aplikatif yang dilakukan Pemerintah Daerah tersebut dilakukan dengan mengikuti tahapan prosedural dan administratif sesuai dengan peratiran-peraturan pemerintah pusat.

Dapat dikatakan bahwa sejauh ini apa yang dilakukan oleh Pemerintah Daerah Kabupaten Bandung Barat tidak menyalahi aturan apabila ditinjau dari perspektif Hukum Administrasi. Segala bentuk kebijakan dan kegiatan sesuai dengan hakekat dari Hukum 
Jurnal Yustika

Vol. 23 No. 01, Jul 2020

Halaman | 21

Analisis Kebijakan

Pemerintah Daerah

dalam Penanganan

Covid-19:

Perspektif Hukum

Administrasi

Ardika Nurfurqon
Administrasi Daerah yaitu bersumber pada hukum atau aturan-aturan diatasnya yang berkaitan dengan Pemerintahan Daerah. Namun ada hal lain yang ingin disampaikan penulis, ialah bahwa terdapat beberapa kelemahan dalam pengimplementasian kebijakan tersebut, kelemahan tersebut diantaranya ialah pemerataan dan penyebaran informasi. Sebagai contoh dalam pembagian bantuan masih belum merata kepada seluruh masyarakat,dalam pencegahan seperti penyemprotan dan pembagian APD belum menyeluruh ke setiap tempat kemudian dari segi informasi belum menyeluruh kepada seluruh masyarakat. Hal lainnya ialah ketika informasi sudah diterima namun masih belum bisa diikuti oleh seluruh masyarakat. Hal-hal tersebut terjadi dikarenakan masyarakat masih harus memenuhi kebutuhan hidupnya yang memang belum bisa terjamin oleh pemerintah daerah. Contohnya Para Pedagang (Gerobak), Ojek, Angkot dan lainnya. Masih ada yang bekerja dan beroprasi. Ini bisa jadi karena belum meratanya bantuan serta kurangnya jaminan yang diberikan pemerintah.

Apabila menilai berdasarkan perspektif berhasilnya kebijakan menurut (Randall B. Repley and Grace A. Franklin 1986) maka kebijakan-kebijakan yang hari ini dikeluarkan belum sepenuhnya berhasil. Dari segi pelaksanaan memang bisa dikatakan berhasil namun dari segi dampak belum bisa dikatakan berhasil karena kita belum mengetahui hasil dari upaya yang dilakukan dalam waktu yang singkat. Selain itu Repley dan Franklin mengatakan salah satu penilaian keberhasilan kebijakan ialah kepatuhan masyarakat terhadap kebijakan yang dilakukan. Bagi penulis sendiri tingkat kepatuhan masyarakat masih belum tinggi, salah satunya sudah dikemukakan diatas ialah karena tidak adanya suatu jaminan bagi masyarakat untuk memenuhi kebutuhan hidupnya selama dilakukannya aturan-aturan untuk pencegahan dan penanganan Covid-19 dan apabila ditinjau dari sisi hukum, hari ini pemerintah mayoritas mengeluarkan surat edaran bukan surat kebijakan atau keputusan. Secara hukum ini belum bisa mengikat masyarakat sebagai objek dari aturan tersebut. Apabila kita lihat hal ini terjadi segaris langsung dari pemerintah pusat, sehingga pemerintah-pemerintah daerah melakukan hal yang sama.

Pemerintah Pusat dan Pemerintah Daerah harus memastikan pemenuhan kebutuhan dasar warga negara dan makanan hewan ternak sebagaimana di atur Pasal 55 ayat (1) pada UU No. 6/2018 Tentang Kekarantinaan Kesehatan yang selanjutnya peperintah menerbitkan pelaksanaannya Peraturan Pemerintah tentang PSBB serta pemerintah daerah menerbitkan Peraturan Bupati tentang Pencegahan Covid-19 yang ditindaklanjuti dengan surat edaran dari Bupati Bandung Barat. Hal ini memberikan gambaran bahwa pemerintah baik pusat maupun daerah perlu diantisipasi potensi konflik sosial yang muncul akibat karantina wilayah dan mengambil langkah tertentu untuk memastikan tidak terjadi diskriminasi sosial terhadap pasien, keluarga pasien dan tenaga kesehatan. Hal tersebut berpotensi mempengaruhi kebijakan dalam pencegahan Covid-19.

Maka penting bagi pemerintah untuk memberikan suatu kepastian, caranya ialah dengan adanya suatu kebijakan yang jelas dan mengikat kepada masyarakat. Maka dengan begitu keberhasilan suatu implementasi kebijakan dirasa akan lebih tinggi. Adapaun tepat atau tidaknya tergantung bagaimana analisis dan kebijakan yang dikeluarkan.

\section{Kesimpulan}

Salah satu problem besar yang harus diselesaikan dewasa ini ialah Pandemi Covid-19. Kebijakan-kebijakan yang tepat dari pemerintah sangatlah diperlukan untuk menangani kasus 
ini. Disisi lain bukan hanya kebijakannya yang tepat melainkan dalam pengimplementasiannya. Salah satu perangkat yang berperan penting dalam pengimplementasian kebijakan ialah Pemerintah Daerah. Pemerintah Daerah adalah tingkatan pemerintah yang lebih tahu akan kondisi daerah serta masyarakatnya.

Secara administratif Pemerintah Daerah khususnya Kabupaten Bandung Barat sudah melakukan pengimplementasian dalam penanganan Covid-19 yaitu dengan karantina wilayah sesuai apa yang dikeluarkan oleh pemerintah pusat. Begitu pula dengan adanya surat-surat edaran guna pencegahan dan penanganan Covid-19. Tentu hal tersebut dikeluarkan atas dasar hukum yang jelas dan tidak menyalahi aturan, yang mana ini menggambarkan kebijakan yang ada sesuai dengan azas hukum administrasi daerah.

Namun terdapat hal yang perlu diperbaiki yaitu dalam pengambilan keputusan dan perancangan dan pelaksanaan kebijakan. Dalam pengambilan keputusan harus berdasarkan peraturan perundang-undangan yang menurut hirarki di atasnya, yang mana secara hukum lebih mengikat masyarakat dan tingkat kepatuhan masyarakat akan lebih tinggi. Sementara dari perancanaan dan pelaksanaan kebijakan agar lebih bisa merata khususnya dalam penginformasian dan ketepatan sasaran karena dua hal tersebut merupakan faktor-faktor penting terimplementasinya suatu kebijakan yang tepat.

\section{Daftar Referensi}

\section{$\underline{\text { Buku }}$}

Abdul Wahab, Solichin. 2012. Analisis Kebijakan, jakarta: Bumi Aksara.

Agus Purwanto, Erwan. 2012. Implementasi Kebijakan Publik Konsep dan Aplikasinya di Indonesia. 2012. Yogyakarta: Grava Media.

Agustino, Leo. 2008. Dasar-dasar Kebijakan Publik. Alfabeta: Bandung.

Atmosudirdjo Prajudi. 1994. Hukum Administrasi. Bandung: Alfabeta.

Dunn, W.A. 2000. Pengantar Analisis Kebijakan Publik (Terjemahan/ Penyunting Muhadjir Darwin dkk). Gadjah Mada University Press. Yogyakarta.

Dwijoyowijoto R.N. 2004. Kebijakan Publik Formulasi, Implementasi, dan Evaluasi. PT. Elex Media Komputindo Kelompok Gramedia. Jakarta

Islamy, M.Irfan. 2009. Prinsip-prinsip Perumusan Kebijakan Negara. Jakarta: Ghalia Indonesia.

Mulyadi, Deddi. 2015. Studi Kebijakan Publik dan Pelayanan Publik (konsep dan aplikasi proses kebijakan dan pelayanan publik). Bandung: Alfabeta.

Nawawi, Ismail. 2009. Public Policy. Surabaya: PMN.

Nugroho, Riant. 2012. Public Policy. Jakarta: Elex Media Komputindo.

Sarundajang.2002. Arus Balik Kekuasaan Pusat ke Daerah cetakan ke 3. Jakarta: Sinar Harapan.

Sugiyono. 2008. Metode Penelitian Kuantitatif, Kualitatif dan RED. Bandung : Alfabeta

Winarno, Budi. 2012. Kebijakan Publik Teori, Proses, dan Studi Kasus. Yogyakarta: CAPS.

\section{Internet}

Rakhmat Nur Hamik,Upadate: Covid-19 di Indonesia Kini 2739 Kasus" di akses melalui https://nasional.kompas.com/read/2020/04/07/16145841/update-covid-19-di-indonesia-kini2738-kasus-bertambah-247 (diakses pada 07 April 2020 Pukul 20.30 WIB) 
Jurnal Yustika Vol. 23 No. 01, Jul 2020

Halaman I 23

Analisis Kebijakan

Pemerintah Daerah dalam Penanganan

\section{Covid-19:}

Perspektif Hukum

Administrasi

Ardika Nurfurqon
RPJM Pemda Kabupaten Bandung Barat Tahun 2010 diakses dari RPIJM Pemda Kabupaten Bandung Barat Tahun 2015-2019 di akses melalui http://sippa.ciptakarya.pu.go.id/sippa_online/ws_file/dokumen/rpi2jm/DOCRPIJM_3a3c8d3e3 $\underline{b \_B A B \% 20 I I B A B \% 202 . p d f}$ (diakses pada 15 April 2020 Pukul 20.45 WIB) 